\title{
CLC wt Allele
}

National Cancer Institute

\section{Source}

National Cancer Institute. CLC wt Allele. NCI Thesaurus. Code C49786.

Human CLC allele is located in the vicinity of 19q13.1 and is approximately $21 \mathrm{~kb}$ in length.

This allele, which encodes eosinophil lysophospholipase protein, is involved in the stimulation of nerve cell survival and in B-cell proliferation. 